\title{
Characterization and Control Strategies of an Integrated Chemical-Biological System for the Remediation of Toxic Pollutants in Wastewater: A Case of Study
}

\author{
Jordi Bacardit, ${ }^{\dagger}$ Carmen Sans, ${ }^{\dagger}$ Ramon Seminago, ${ }^{\ddagger}$ and Santiago Esplugas ${ }^{*}, \dagger$ \\ Chemical Engineering Department, University of Barcelona, Martí i Franquès 1, 08028 Barcelona, Spain, and \\ Unitat de Genòmica, Parc Científic de Barcelona, Baldiri Reixac 10-12, 08028 Barcelona, Spain
}

In a previous work, a hybrid system consisting of an advanced oxidation process (AOP) named Photo-Fenton $(\mathrm{Ph}-\mathrm{F})$ and a fixed bed biological treatment operating as a sequencing batch biofilm reactor (SBBR) was started-up and optimized to treat $200 \mathrm{mg} \cdot \mathrm{L}^{-1}$ of 4-chlorophenol (4-CP) as a model compound. In this work, studies of reactor stability and control as well as microbial population determination by molecular biology techniques were carried out to further characterize and control the biological reactor. Results revealed that the integrated system was flexible and even able to overcome toxic shock loads. Oxygen uptake rate (OUR) in situ was shown to be a valid tool to control the SBBR operation, to detect toxic conditions to the biomass, and to assess the recovery of performance. A microbial characterization by $16 \mathrm{~S}$ rDNA sequence analysis reveals that the biological population was varied, although about $30 \%$ of the bacteria belonged to the Wautersia genus.

\section{Introduction}

The need for fresh water in our time has become a problem of important concern. Many sources have been exhausted, and other sources are likely to be polluted due to the industrial activity. Most persistent chemicals discharged into the aquatic environment are toxic and/or recalcitrant to biodegradation. Therefore, they are not easily removed by biological means. Alternative separation techniques do not really solve the problem. The need to restore water for new uses makes water purification essential to achieve a desired degree of quality. To this end, other suitable wastewater treatment technologies that achieve actual contaminant destruction have to be developed.

In the last decades, an important class of technologies named advanced oxidation processes (AOPs) has emerged as suitable for accelerating the oxidation and destruction of a wide range of organic contaminants in polluted water. ${ }^{1}$ Among these processes is included Photo-Fenton (Ph-F). A major drawback of AOPs in general, and in particular of Photo-Fenton, is that they might involve high operating costs if high levels or total mineralization are to be achieved. However, the use of AOPs is more suitable or even indispensable when the contaminant to be treated is not easily biodegradable or when the amount of organic matter is low. One economically viable option to treat wastewater containing nonbiodegradable pollutants consists of combining an AOP, like Photo-Fenton, and a biological posttreatment. The hybrid system combines the capacity of PhotoFenton to reduce toxicity and enhance biodegradability, ${ }^{2}$ with lower operating costs associated with the biological treatment.

Several studies have shown that discontinuous processes such as sequencing batch reactors (SBR) present some advantages for biodegrading xenobiotic compounds. In SBR, there is a selection of microbial community with a vast metabolic range in which microbial species can differ greatly in growth rate and yield $^{3}$ and are thus able to degrade problematic compounds. ${ }^{4}$ Among SBRs, the attached-growth SBR may be distinguished. The attached growth SBR is named the sequencing batch biofilm reactor (SBBR). Its main feature is the fixed bed of biomass. In these systems, a high bioreactor activity is achieved by means

* To whom correspondence should be addressed. Tel.: +34 93 4021290. Fax: +34 934021291. E-mail: santi.esplugas@ub.edu.

University of Barcelona.

${ }_{*}^{*}$ Parc Científic de Barcelona. of a large biomass concentration. ${ }^{5}$ Biofilms also result in long biomass residence times, which make them particularly suitable when treatment requires slow growing organisms with poor biomass yield or when the wastewater concentration is too low to support growth of activated sludge flocks. ${ }^{6,7}$

Recent studies ${ }^{3}$ have shown that by measuring only the dissolved oxygen concentration and the volume of the reactor, it is possible to estimate the oxygen uptake rate (OUR), which is linearly related to the substrate uptake rate (SUR). Using this estimation, the optimal strategy sets the influent flow rate such that the substrate degradation rate is maximized as long as possible, thus, minimizing the reaction time. As the experimentation deals with an immobilized biomass reactor, the estimation of OUR must be carried out in situ. ${ }^{8}$

Identification of microorganisms by conventional methods requires the isolation of pure cultures followed by laborious characterization experiments. These procedures are therefore inadequate for study of the biodiversity of a natural or engineered ecosystem. Therefore, for decades, a biological reactor has been lacking characterization of complex microbial communities. A new set of molecular techniques developed during the 1990s revolutionized microbial ecology research. Modern molecular techniques, including environmental genomics, have identified unexpected microbial key players for nutrient removal and sludge bulking and/or foaming in wastewater treatment plants and provided many exciting insights into the diversity, functions, and niche differentiations of these predominantly uncultivated microorganisms. ${ }^{9}$ Among these techniques, cloning and the creation of a gene library stands out. Cloning provides very precise taxonomical information, although further combined effort of microbiologist and engineers is necessary to relate microbial population with properties of functionality of the biological reactors. ${ }^{10-12}$

The main scope of this work is to characterize and to study control possibilities of the biological reactor of a hybrid PhotoFenton-sequencing batch biofilm reactor to treat $200 \mathrm{mg} \cdot \mathrm{L}^{-1}$ of 4-chlorophenol (4-CP) as a model compound. Two different pretreated effluents are fed to the biological reactor: one readily biodegradable and one partially biodegradable. To this end, different parameters are estimated such us oxygen up rate (OUR), oxygen consumption (OC), and heterotrophic yield $\left(Y_{\mathrm{H}}\right)$. 
Moreover, the bacterial population of the bioreactor is characterized by means of molecular biology techniques.

\section{Materials and Methods}

Photo-Fenton Experiments: Device and Procedures. The photo-Fenton reactor consisted of a $2.2 \mathrm{~L}$ cylindrical jacketed reservoir, with 3 UV $8 \mathrm{~W}$ fluorescent tubes placed inside (Philips F8T5/BLB; 340-400 nm with a maximum at $370 \mathrm{~nm}$ ). The vessel was covered with aluminum foil to avoid external influences. The device was also equipped with a magnetic stirrer. Photon flow input to the system was estimated to be constant (3.61 $\mu$ Einstein/s) by means of actinometry. ${ }^{13}$ A scheme of the installation may be found in previously published work. ${ }^{14}$

The target solution consisted of $2 \mathrm{~L}$ of $200 \mathrm{mg} \cdot \mathrm{L}^{-1}(1.56$ $\mathrm{mM}$ ) 4-chlorophenol (4-CP) aqueous solution. The necessary amounts of $\mathrm{FeSO}_{4} \cdot 7 \mathrm{H}_{2} \mathrm{O}$ to obtain a $\mathrm{Fe}^{2+}$ concentration of 10 $\mathrm{mg} \cdot \mathrm{L}^{-1}$ were added and the volume was brought to $2 \mathrm{~L}$. The initial $\mathrm{pH}$ was adjusted to 2.8. The temperature was held constant at $27{ }^{\circ} \mathrm{C}$ by a water bath. The UV fluorescent lamps were switched on in order to reach stable irradiation. After $5 \mathrm{~min}$, the necessary amount of $\mathrm{H}_{2} \mathrm{O}_{2}$ was added into the reactor. The system was left to react until all the $\mathrm{H}_{2} \mathrm{O}_{2}$ was consumed. $\mathrm{H}_{2} \mathrm{O}_{2}$ consumption was followed using Quantofix test sticks (Macherey-Nagel). The consequent product was identified as $\mathrm{Ph}-\mathrm{F}$ product or effluent. Over the process, samples were withdrawn in timed intervals and analyzed by chromatography-HPLC and total organic carbon (TOC). Chemical and biochemical oxygen demand (COD and $\mathrm{BOD}_{5}$, respectively) of the final product were measured according to the standard methods 5220D and 5210D, respectively. ${ }^{15}$ TOC and COD determination allowed calculating the average oxidation state $(\mathrm{AOS})^{16}$ (eq 1), that characterize the oxidation grade of the organic matter resulted from the $\mathrm{Ph}-\mathrm{F}$ treatment.

$$
\mathrm{AOS}=\frac{4(\mathrm{TOC}-\mathrm{COD})}{\mathrm{TOC}}
$$

Fixed-Bed Biological Reactor: SBBR. Device and Procedure. The effluent that results from the $\mathrm{Ph}-\mathrm{F}$ treatment must be conditioned before being fed into the biological reactor. First, the solution was neutralized to $\mathrm{pH}$ around 7 by means of $\mathrm{NaOH}$ and buffered with sodium dihydrogen phosphate solution $1.5 \mathrm{~N}$ ( $6 \mathrm{~mL}$ of buffer per liter of feed). Next, $2 \mathrm{~mL}$ of the following solutions per liter of feed were added; ammonium chloride $0.71 \mathrm{~N}$, magnesium sulfate $0.41 \mathrm{~N}$, ferric chloride 0.018 $\mathrm{N}$, and calcium chloride $0.25 \mathrm{~N}$.

The biological reactor was a $2.5 \mathrm{~L}$ glass jacketed column filled with porous material to serve as a support to the microorganisms. The vessel is a jacketed cylinder and follows a height/diameter ratio of 3 to 1 . The support occupied a volume of $0.9 \mathrm{~L}$, resulting in a void of $1.6 \mathrm{~L}$ of liquid. The device was equipped with feeding, recirculation, and draw-off pumps (ColeParmer). Air was fed at a flow rate of $2 \mathrm{~L} \cdot \mathrm{min}^{-1}$. An electrovalve was used as a check valve in order to hold back the liquid when the air was stopped. The power supply to the feeding, recirculation, and draw-off pumps, air compressor, and check valve were controlled by a time-based control system (Siemens LOGO! $230 \mathrm{RC}$ ). The temperature at the reactor was controlled by a water bath (Haake DC10-K10) at $27^{\circ} \mathrm{C}$. The aerobic sludge $\left(\mathrm{TVSS}=2000 \mathrm{mg} \cdot \mathrm{L}^{-1}\right)$ taken from a STP located in Barcelona (Spain) was used as inoculum.The complete device is depicted in Figure 1. The samples withdrawn were filtrated using 0.45 $\mu \mathrm{m}$ polyethersulphone (PES) filters and acidified in order to monitor TOC, COD, and TVSS (total volatile suspended solids; standard method 2540E).

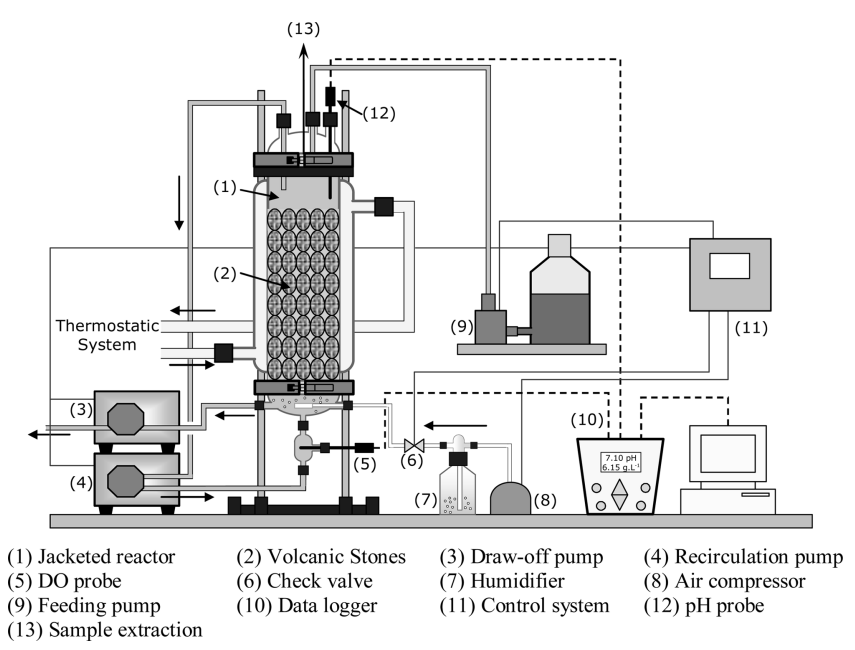

Figure 1. Sequencing batch biofilm reactor (SBBR) scheme.

Feed A. Initially, the SBBR was charged with feed A, that is photo-Fenton effluent resulting from using $500 \mathrm{mg} \cdot \mathrm{L}^{-1}$ of initial $\mathrm{H}_{2} \mathrm{O}_{2}$ concentration and $10 \mathrm{mg} \cdot \mathrm{L}^{-1}$ of $\left[\mathrm{Fe}^{2+}\right]_{0}$. First of all, a start-up of the SBBR was carried out with the objective of forming the biofilm. For this purpose, the SBBR was filled with feed $\mathrm{A}$ and an initial high concentration of TVSS was inoculated $\left(1000 \mathrm{mg} \cdot \mathrm{L}^{-1}\right)$. After the start-up with $168 \mathrm{~h}$ of hydraulic retention time (HRT), the reduction of HRT started with 5 day cycles $($ HRT $=120 \mathrm{~h}$ ), was followed by a group of cycles at $48 \mathrm{~h}$ ( 2 days), then some cycles of $24 \mathrm{~h}$, and ended in a collection of cycles in which HRT was $8 \mathrm{~h}$. Cycles were repeated without changing the HRT until steady state was achieved.

Feed B. Aiming to study SBBR performance when feed with a partially biodegradable influent, different duration cycles were carried out filling the reactor with feed $\mathrm{B}$ (photo-Fenton effluent resulting from using just $300 \mathrm{mg} \cdot \mathrm{L}^{-1}$ of initial $\mathrm{H}_{2} \mathrm{O}_{2}$ concentration and $10 \mathrm{mg} \cdot \mathrm{L}^{-1}$ of $\left[\mathrm{Fe}^{2+}\right]_{0}$ ).

In situ Characterization of Biological Activity. Dissolved $\mathrm{O}_{2}$ (DO) was monitored with a DO probe (Symphony, VWR) in all cycles. The air supply was shortly interrupted in order to calculate oxygen uptake rates (OURs) using the slope of the DO decay between 6.5 and $2.5 \mathrm{mg} \mathrm{O}_{2} \mathrm{~L}^{-1}$. 9 These OURs are representative of the biomass activity and their interpretation allows deciding when cycles reach steady state and which hydraulic retention time (HRT) should be assessed next. As it is known, OUR values have a direct relation with the substrate uptake rate (SUR), which is the COD degradation rate, characteristic of the bioreactor activity.

Heterotrophic yield $\left(Y_{\mathrm{H}}\right)$ is defined as the relation between the new biomass generated per amount of substrate consumed. $Y_{\mathrm{H}}$ was estimated using the equations described in the IAWQ activated sludge model no. 1 (ASM1). ${ }^{17}$ Integrating the area, the total oxygen consumption $\left(\mathrm{OC}_{\mathrm{Total}}\right)$ of a cycle could be determined.

Characterization of Microbial Diversity. During the operation of the SBBR, a support sample from the reactor was collected in order to extract the DNA of a bacterial community, using a FastDNA SPIN for Soil Kit (QBIOgene). Once the DNA was extracted, an amplification stage targeting the gene 16SrRNA in an Applied BioSystems 9700 Thermocycler by means of polymerase chain reaction (PCR) was carried out, using an Eppendorf Master Mix (2.5×). The 16SrDNA PCR products for clone library construction were ligated into vector PCR2.1-TOPO using the TOPO TACloning Kit (Invitrogen, 
Table 1. Ph-F Products Characterization Results Summary ${ }^{a}$

\begin{tabular}{|c|c|c|c|c|c|c|}
\hline $\begin{array}{c}\mathrm{H}_{2} \mathrm{O}_{2} \text { dose } \\
\left(\mathrm{mg} \cdot \mathrm{L}^{-1}\right)\end{array}$ & $\begin{array}{c}\mathrm{COD}_{\mathrm{f}} \\
\left(\mathrm{mg} \mathrm{O}_{2} \cdot \mathrm{L}^{-1}\right)\end{array}$ & $\begin{array}{c}\mathrm{BOD}_{5, \mathrm{f}} \\
\left(\mathrm{mg}_{2} \cdot \mathrm{L}^{-1}\right)\end{array}$ & $\mathrm{BOD}_{\mathrm{f}} / \mathrm{COD}_{\mathrm{f}}$ & $\begin{array}{c}\mathrm{TOC}_{\mathrm{f}} \\
\left(\mathrm{mg} \mathrm{C} \cdot \mathrm{L}^{-1}\right)\end{array}$ & AOS & $\begin{array}{c}\text { chloride } \\
\left(\mathrm{mg} \mathrm{Cl} \mathrm{Cl}^{-} \cdot \mathrm{L}^{-1}\right)\end{array}$ \\
\hline 0 & 320 & 1.5 & 0.004 & 112 & -0.42 & 0.00 \\
\hline 50 & 280 & 16.1 & 0.06 & 108 & 0.12 & 10.6 \\
\hline 100 & 259 & 20.6 & 0.08 & 105 & 0.30 & 31.9 \\
\hline 200 & 210 & 24.0 & 0.11 & 100 & 0.85 & 42.5 \\
\hline 300 & 171 & 27.1 & 0.16 & 95.3 & 1.30 & 53.2 \\
\hline 400 & 124 & 23.7 & 0.19 & 77.3 & 1.60 & \\
\hline 500 & 91 & 18.4 & 0.20 & 55.0 & 1.52 & 56.7 \\
\hline
\end{tabular}

${ }^{a} \mathrm{Fe}^{2+}=10 \mathrm{mg} \cdot \mathrm{L}^{-1} ; T=27^{\circ} \mathrm{C}$.

Carlsbad, CA). Selected clones were grown in agar-Petri plates amended with $50 \mu \mathrm{g} \cdot \mathrm{mL}^{-1}$ of ampicillin. Following harvesting, plasmid DNA from 96 randomly chosen isolated colonies was purified from cell pellets using a Qiaprep Spin Miniprep Kit (Qiagen). 16S rDNA reamplification and sequencing of clones were performed using a BigDye Terminator v3.1 Cycle Sequencing Kit (Applied BioSystems), and finally, a DNA sequencing was performed in an ABI Prism 3730XL DNA Sequencer (Applied BioSystems). At last, each one of the 96 DNA sequences obtained in the sequencer was compared in the Basic Local Alignment Search Tool (BLAST) Database from the National Center of Biotechnology Information (NCBI) and in the Ribosomal Database Project II database from the Michigan Institute of Technology, in order to identify the types of bacteria that correspond to the extracted DNA samples.

\section{Results and Discussion}

The SBBR reactor was characterized at the best-known operating conditions, i.e, those related to the final biodegradability of photo-Fenton pretreatment effluent (feed A). In a second stage, the reactor was characterized when the solution fed into the SBBR was less biodegradable, since it is treated in the Photo-Fenton with a smaller amount of $\mathrm{H}_{2} \mathrm{O}_{2}$ (feed B). Finally, the SBBR reactor was exposed to a nonreadily biodegradable and toxic substrate or even to solution of 200 $\mathrm{mg} \cdot \mathrm{L}^{-1}$ of $4-\mathrm{CP}$ with no-pretreatment, what can be defined a shock load. These circumstances might occur in the case of control failure in the photo-Fenton process, and the pretreatment caused by this failure becomes null. Reactor recuperation after feeding with readily biodegradable influent was also studied.

Characterization of Ph-F Effluents. Table 1 presents results of the Ph-F treatment on both feeds (A and B). 4-Chlorophenol was completely removed in both pretreatments, and the TOC abatements achieved at the end of the reactions were 15 and $50 \%$ for solutions $\mathrm{A}$ and $\mathrm{B}$, respectively. The oxidized intermediates resulted with a final $\mathrm{BOD}_{5} / \mathrm{COD}$ ratio of 0.16 for feed A and 0.20 for feed B. More detailed information is presented and discussed elsewhere. ${ }^{14}$

Operation with Readily Biodegradable Matter (Feed A). The SBBR was started up with a Ph-F product obtained with $500 \mathrm{mg} \cdot \mathrm{L}^{-1}$ of $\mathrm{H}_{2} \mathrm{O}_{2}$ and $10 \mathrm{mg} \cdot \mathrm{L}^{-1}$ of $\left[\mathrm{Fe}^{2+}\right]_{0}$, which was the most readily biodegradable product tested (Feed A). More than $90 \%$ mineralization was achieved with the hybrid process with just $8 \mathrm{~h}$ of HRT in the biological reactor. Interestingly, the biodegradability ratio of $\mathrm{BOD}_{5} / \mathrm{COD}$ for PhotoFenton products did not seemed to predict the achieved biodegradation in the SBBR. There was only a carbon content of approximately $10 \mathrm{mg} \cdot \mathrm{L}^{-1}$ in the SBBR effluent. This value is reasonably attributable to biomass lyses products. ${ }^{18}$

Figure 2 shows a typical OUR profile, when the SBBR was operated with an HRT of $8 \mathrm{~h}$. The profile indicates clearly a first period of high activity, which coincides with the observed COD profile (not shown). After $4 \mathrm{~h}$, the oxidation activity was

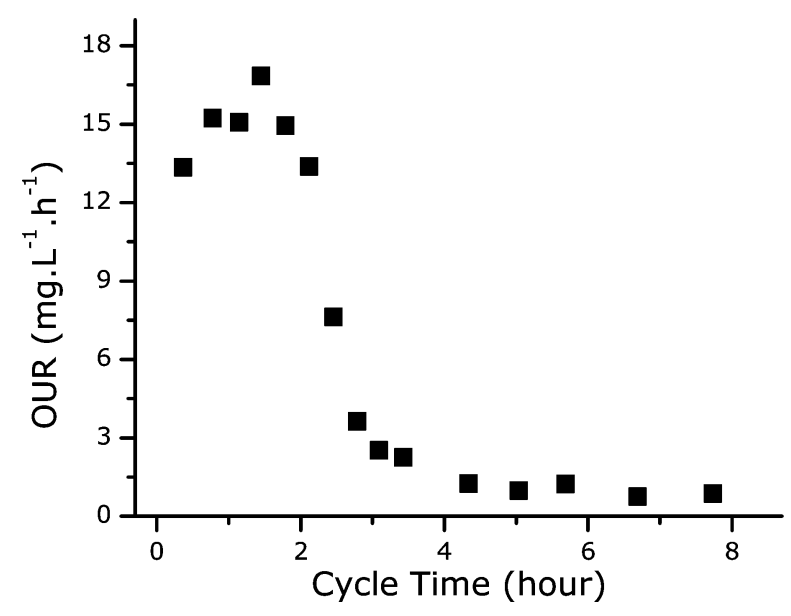

Figure 2. Typical OUR profile (cycle 49): feed A (Photo-Fenton pretreatment with $500 \mathrm{mg} \cdot \mathrm{L}^{-1}$ of $\mathrm{H}_{2} \mathrm{O}_{2}$ and $10 \mathrm{mg} \cdot \mathrm{L}^{-1}$ of $\left.\left[\mathrm{Fe}^{2+}\right]_{0}\right)$; HRT $=8 \mathrm{~h}$.

Table 2. Summary of SBBR Results of Cycles Fed with Ph-F Effluent Treated with $\left[\mathrm{H}_{2} \mathrm{O}_{2}\right]_{0}=500 \mathrm{mg} \cdot \mathrm{L}^{-1}$ and $\left[\mathrm{Fe}^{2+}\right]_{0}=10$ $\mathbf{m g} \cdot \mathbf{L}^{-1}$

\begin{tabular}{ccccc}
\hline cycle & HRT (h) & $\begin{array}{c}\mathrm{COD}_{\text {removed }} \\
\left(\mathrm{mg} \cdot \mathrm{L}^{-1}\right)\end{array}$ & $\begin{array}{c}\mathrm{OC}_{\mathrm{COD}} \\
\left(\mathrm{mg} \cdot \mathrm{L}^{-1}\right)\end{array}$ & $\begin{array}{c}\text { yield } \\
(Y ; \mathrm{mg} / \mathrm{mg})\end{array}$ \\
\hline 21 & 168 & 44.6 & 40.4 & 0.09 \\
23 & 120 & 39.5 & 37.2 & 0.06 \\
28 & 48 & 37.3 & 32.4 & 0.13 \\
33 & 24 & 35.8 & 32.2 & 0.10 \\
49 & 8 & 42.8 & 33.4 & 0.2
\end{tabular}

characterized by OUR falls to very low values, which indicate that the bacterial population was in the endogenous phase. According to this profile, it would be possible to optimize the system operation by reducing HRT.

Table 2 summarizes the results of cycles fed with $\mathrm{Ph}-\mathrm{F}$ effluent treated with $500 \mathrm{~g} \cdot \mathrm{L}^{-1}$ of $\mathrm{H}_{2} \mathrm{O}_{2}$, as the HRT of SBBR was shortened. The table shows the amount of COD removed in the SBBR ( $\mathrm{COD}_{\text {removed }}$ ), the amount of oxygen consumed for $\mathrm{COD}$ oxidation $\left(\mathrm{OC}_{\mathrm{COD}}\right)$, and heterotrophic yield estimation $\left(Y_{\mathrm{H}}\right)$ for all the operating conditions that were tested. It can be emphasized that there were no significant differences of these parameters among the different operating conditions, which means that the influent was readily biodegradable. In so far as the organic loading rate increased (hydraulic retention time decreased), the population was able to degrade biodegradable carbon faster, probably because there was a significant population growth. Consequently, reactor stability was not affected. As explained, an important feature of bacterial sequencing batch reactors (SBR) is the ability to change its populations in order to become acclimatized to new situations. ${ }^{19}$ Yield values obtained in all working conditions studied were low, which means that new biomass production was low and the sludge age of SBBR was high. 
Table 3. Summary of SBBR Results of Cycles Fed with Ph-F Effluent Prepared with $\left[\mathrm{H}_{2} \mathrm{O}_{2}\right]_{0}=300 \mathrm{mg} \cdot \mathrm{L}^{-1}$ and $\left[\mathrm{Fe}^{2+}\right]_{0}=10$ $\mathbf{m g} \cdot \mathbf{L}^{-1}$

\begin{tabular}{|c|c|c|c|c|c|c|c|}
\hline cycle & $\begin{array}{l}\text { HRT } \\
\text { (h) }\end{array}$ & $\begin{array}{l}\text { final TOC } \\
\left(\mathrm{mg} \cdot \mathrm{L}^{-1}\right)\end{array}$ & $\begin{array}{l}\text { final COD } \\
\left(\mathrm{mg} \cdot \mathrm{L}^{-1}\right)\end{array}$ & AOS & $\begin{array}{l}\mathrm{COD}_{\text {removed }} \\
\left(\mathrm{mg} \cdot \mathrm{L}^{-1}\right)\end{array}$ & $\begin{array}{c}\mathrm{OC}_{\mathrm{COD}} \\
\left(\mathrm{mg} \cdot \mathrm{L}^{-1}\right)\end{array}$ & $\begin{array}{c}\text { yield } \\
(Y ; \mathrm{mg} / \mathrm{mg})\end{array}$ \\
\hline 57 & 168 & 23.0 & 40.4 & 1.4 & 100 & 32.2 & 0.68 \\
\hline 58 & 120 & 24.8 & 42.6 & 1.4 & 100 & 54.9 & 0.45 \\
\hline 63 & 48 & 29.6 & 59.3 & 1.0 & 67.5 & 30.2 & 0.55 \\
\hline 71 & 24 & 36.8 & 72.5 & 1.0 & 62.6 & 39.1 & 0.38 \\
\hline 87 & 8 & 45.6 & 94.2 & 0.9 & 40.3 & 38.1 & 0.05 \\
\hline
\end{tabular}

Table 4. Summary of SBBR Results: Operation with Less Biodegradable Feed, Toxic Shock Loads, and Recovery Period ${ }^{a}$

\begin{tabular}{|c|c|c|c|c|}
\hline cycle & $\begin{array}{c}\mathrm{H}_{2} \mathrm{O}_{2} \text { in } \\
\mathrm{Ph}-\mathrm{F}\left(\mathrm{mg} \cdot \mathrm{L}^{-1}\right)\end{array}$ & $\begin{array}{c}\mathrm{OC}_{\text {total }} \\
\left(\mathrm{mg} \mathrm{O}_{2} \cdot \mathrm{L}^{-1}\right)\end{array}$ & $\begin{array}{l}\text { final COD } \\
\left(\mathrm{mg} \mathrm{O}_{2} \cdot \mathrm{L}^{-1}\right)\end{array}$ & $\begin{array}{c}\text { final TOC } \\
\left(\mathrm{mg} \mathrm{C}^{\circ} \mathrm{L}^{-1}\right)\end{array}$ \\
\hline 49 & 500 & 41.1 & 19.0 & 16.9 \\
\hline 87 & 300 & 52.7 & 94.2 & 45.6 \\
\hline 118 & 200 & 18.2 & 136 & 68.9 \\
\hline 121-shock1 & 100 & 19.3 & 160 & 70.0 \\
\hline 136 & 500 & 42.9 & 27.8 & 18.3 \\
\hline 142-shock2 & 50 & 16.7 & 113 & 47.9 \\
\hline 157 & 500 & 45.4 & 30.4 & 16.6 \\
\hline 160-shock3 & 0 & 12.4 & 167 & 58.1 \\
\hline 163 & 500 & 52.5 & 33.6 & 26.6 \\
\hline
\end{tabular}

Operation with Partially Biodegradable Matter (Feed B). The aim of this section was the characterization of the reactor and biomass with a partially biodegradable feed. In this case, the solution to be treated in the SBBR was the product obtained by Photo-Fenton treatment of $200 \mathrm{mg} \cdot \mathrm{L}^{-1}$ of 4 -CP pretreated in the $\mathrm{Ph}-\mathrm{F}$ with $300 \mathrm{mg} \cdot \mathrm{L}^{-1}$ of $\left[\mathrm{H}_{2} \mathrm{O}_{2}\right]_{0}$ and $10 \mathrm{mg} \cdot \mathrm{L}^{-1}$ of $\left[\mathrm{Fe}^{2+}\right]_{0}$ (feed $\left.\mathrm{B}\right)$. With the integrated process at these operating conditions it was possible to abate more than $70 \%$ of the initial TOC. This result was inferior to the one obtained with feed A, but most of the total TOC abatement occurs in the biological treatment. Moreover, in this case it was possible to distinguish between readily and slowly biodegradable substrate.

Table 3 shows a summary of results depending on the applied HRT. As HRT was shorter, the bacterial culture tended to consume less organic matter. Furthermore, the difference between COD and TOC increased. This might point out that the readily biodegradable fraction, which was consumed first, was more oxidized than the slowly biodegradable species, which were only digested in longer cycles.

Interestingly, yield did not follow the same trend observed using feed A. Instead of increasing with shorter HRT, in this occasion, it decreased significantly. Furthermore, yield values for the longest cycles were significantly higher than the ones assessed in the previous part. In the present case, it seems that, in short cycles, biomass only consumed highly biodegradable substrate, unlike in longer cycles, where it consumed both kinds of substrates.

Operation with Less Biodegradable Feed and Toxic Shock Loads. In this section, the reactor was first operated with a nonreadily biodegradable feed, prepared by $\mathrm{Ph}-\mathrm{F}$ with 200 $\mathrm{mg} \cdot \mathrm{L}^{-1}$ of $\mathrm{H}_{2} \mathrm{O}_{2}$ and $10 \mathrm{mg} \cdot \mathrm{L}^{-1}$ of $\left[\mathrm{Fe}^{2+}\right]_{0}$. The product still contained potentially inhibitory substances, such as 4-chlorophenol (4-CP) and 4-chlorocatechol (4-CC). The latter was a byproduct of $\mathrm{Ph}-\mathrm{F}$ oxidation of 4-chlorophenol. Once the reactor was at steady state, toxic shock loads were studied. The first shock was carried out with a solution prepared by Ph-F with $100 \mathrm{mg} \cdot \mathrm{L}^{-1}$ of $\mathrm{H}_{2} \mathrm{O}_{2}$; the second, prepared with $50 \mathrm{mg} \cdot \mathrm{L}^{-1}$; and the final, with directly a solution of $200 \mathrm{mg} \cdot \mathrm{L}^{-1}$ of $4-\mathrm{CP}$. Between one shock and the following, the SBBR was fed with the readily biodegradable substrate previously described until a recovery was observed.

The SBBR started operation fed with a solution treated by Photo-Fenton with $200 \mathrm{mg} \cdot \mathrm{L}^{-1}$ of $\mathrm{H}_{2} \mathrm{O}_{2}$. In a first cycle, HRT was maintained at $120 \mathrm{~h}$ (5 days), and subsequently reduced down to $8 \mathrm{~h}$. As it happened with the feed prepared with 300 $\mathrm{mg} \cdot \mathrm{L}^{-1}$, insofar as HRT was reduced, the SBBR was able to degrade less COD and mineralize less TOC. With an HRT of 8 h, only $40 \%$ of TOC and around $60 \%$ of COD was degraded considering the combination of Photo-Fenton and biological treatments.

Then, the described toxic shock loads were carried out. Table 4 shows a summary of results. $\mathrm{OC}_{\mathrm{Total}}$ is the total amount of oxygen that was consumed during a cycle and was measured by numerical integration of the in situ OUR. By comparison, it is clearly observed the influence that a toxic shock load of the higher chlorinated compounds 4-TCP and 4-chlorocatechol had on the SBBR activity. After shocks 1 and 2, it was necessary to repeat more than 10 cycles in order to reach similar levels of consumed oxygen $\left(\mathrm{OC}_{\text {total }}\right)$ than in cycle 49 , which was fixed as a standard cycle with the readily biodegradable feed. Interestingly, with the last shock load (shock 3), which was carried out with $200 \mathrm{mg} \cdot \mathrm{L}^{-1}$ of $4-\mathrm{CP}$ with no previous treatment, the SBBR apparently recovered faster than with the previous shocks (just after 2 cycles). Probably, some of the early intermediates of 4-CP degradation, which were present mainly in shock 2, were even more toxic than 4-CP. These results suggest that acclimation of the microbial population to toxic loads during the reactor operation had led to greater reactor stability.

In conclusion, the SBBR seemed to overcome shock loads easily in most of the cases. Even with the most toxic conditions,

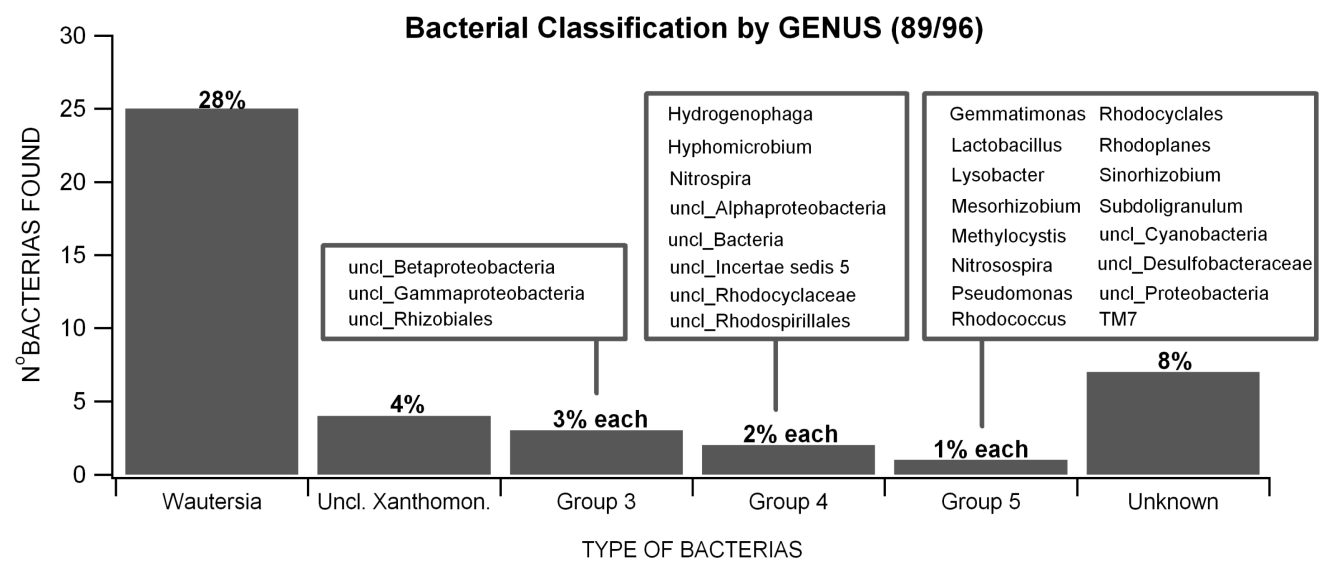

Figure 3. Bacterial population classification by genus. 
the SBBR was able to recover and achieve similar values of treatment than the ones observed before the toxic load. Furthermore, if $\mathrm{OC}_{\text {total }}$ can be automatically monitored, it can provide a method to control malfunctioning of the reactor and its desired recuperation. When using biofilm processes, the inner layer of microorganisms is protected, tolerating high concentration of toxic substances or toxic shock loading. This feature entails a significant advantage over other reactor configurations and places it as an important technology for the treatment of toxic and biorecalcitrant organic pollutants.

Characterization of a Microbial Population. Finally, the characterization of the microbial diversity of the SBBR operating in the best conditions (feed A) was carried out by cloning and sequencing bacterial $16 \mathrm{~S}$ rDNA. A total of 89 bacterial $16 \mathrm{~S}$ rDNA genes have been sequenced and subjected to phylogenetic analysis. Results are depicted in Figure 3, which is a bacterial classification by genus.

The most occurring clone types obtained from the biofilm sample of the reactor were related to the Proteobacteria with over $70 \%$, dominated by sequences almost identical to the bacterium Wautersia, which represented up to the $28 \%$ of the retrieved sequences. Wautersia genus strains have been related with bacteria involved in chlorinated hydrocarbon degradation. ${ }^{20}$ Another important group of clones belonged to Xanthomonas phylotype (4\% of clones) which have been found as dominant group in bacterial community degrading aromatic hydrocarbons. $^{21}$ This study shows that identification of microbial diversity is a promising tool for the control of process performance.

\section{Conclusions}

The combination of photo-Fenton and SBBR biological processes is shown to be a viable strategy for the treatment of toxic wastewaters.

The SBBR was studied in depth in order to characterize its operation depending on the Photo-Fenton pretreatment conditions and the hydraulic retention time (HRT). The SBBR was able to mineralize an important part of organic matter supplied and did not present difficulties when the carbon supply per time was high (low HRT). When the SBBR was fed with a readily biodegradable mixture, prepared with a photo-Fenton pretreatment with $500 \mathrm{mg} \cdot \mathrm{L}^{-1}$ of $\mathrm{H}_{2} \mathrm{O}_{2}$ and $10 \mathrm{mg} \cdot \mathrm{L}^{-1}$ of $\left[\mathrm{Fe}^{2+}\right]_{0}$, the reactor acclimatized fast and was able to treat efficiently at low HRT, even less than $8 \mathrm{~h}$ of treatment.

When the substrate was pretreated with less $\mathrm{H}_{2} \mathrm{O}_{2}(300$ $\mathrm{mg} \cdot \mathrm{L}^{-1}$ ), its effects on the SBBR were more complex. Below a certain cycle time, the SBBR was not able to treat the same organic matter than at the longest cycles. When the organic carbon load was high, the reactor become acclimated to rapidly consume the most biodegradable fraction and avoided degradation of the difficult fraction.

Furthermore, the bioreactor showed high resistance when is exposed to toxic shock load and was able to recover fairly well. Long-term acclimation to less biodegradable feed turned the reactor more stable in front of toxic loads and made its recovery from shocks loads faster.

Concerning control possibilities, the falling of dissolved oxygen when air supply was shortly stopped, which is the socalled in situ oxygen uptake rate (OUR), is suggested to be a good parameter for reactor control, since it is a direct measurement of bacterial activity.

Characterization of microbial diversity enabled the detection of bacteria involved in process of degradation of chlorinated and aromatic hydrocarbons. Multidisciplinary research groups are responsible of stimulating leading-edge technologies.

\section{Acknowledgment}

The authors thank the different organizations that granted this project: Ministry of Education and Science of Spain (projects CTQ2005-00446/PPQ and CTQ2008-01710/PPQ).

\section{Literature Cited}

(1) Glaze, W. H.; Kang, J. W.; Chapin, D. H. The Chemistry of WaterTreatment Processes Involving Ozone, Hydrogen-Peroxide and UltravioletRadiation. Ozone Sci. Eng. 1987, 9 (4), 335-352.

(2) Sarria, V.; Kenfack, S.; Guillod, O.; Pulgarin, C. An innovative coupled solar-biological system at field pilot scale for the treatment of biorecalcitrant pollutants. J. Photochem. Photobiol. A-Chem. 2003, 159 (1), 89-99.

(3) Moreno-Andrade, I.; Buitron, G. N.; Betancur, M. J.; Moreno, J. A. Optimal degradation of inhibitory wastewaters in a fed-batch bioreactor. J. Chem. Technol. Biotechnol. 2006, 81 (4), 713-720.

(4) Buitron, G.; Quezada, M.; Moreno, G. Aerobic degradation of the azo dye acid red 151 in a sequencing batch biofilter. Biores. Technol. 2004, 92 (2), 143-149.

(5) Grady, C. P. L. Biodegradation of Toxic Organics - Status and Potential. J. Environ. Eng-Asce 1990, 116 (5), 805-828.

(6) Wilderer, P. A. Sequencing batch biofilm reactor technology. Harnessing biotechnology for the 21st century; American Chemical Society: Washington, D.C., 1992.

(7) Wilderer, P. A., Irvine, R. L. Goronszy, M. C. Sequencing Batch Reactor Technology; IWA Publishing: London, 2001.

(8) Yoong, E. T.; Lant, P. A.; Greenfield, P. F. In situ respirometry in an SBR treating wastewater with high phenol concentrations. Water Res. 2000, 34 (1), 239-245.

(9) Daims, H.; Taylor, M. W.; Wagner, M. Wastewater treatment: a model system for microbial ecology. Trends Biotechol. 2006, 24 (11), 483489.

(10) Rittmann, B. R. Microbial ecology to manage processes in environmental biotechnology. Trends Biotechol. 2006, 24 (6), 261-266.

(11) Sanz, J. L.; Köchling, T. Molecular biology techniques used in wastewater treatment: An overview. Process Biochem. 2007, 42, 119-133.

(12) Lee, H.; Choi, E.; Yun, Z.; Park, Y. K. Microbial structure and community of RBC biofilm removing nitrate and phosphorus from domestic wastewater. J. Microbiol. Biotechnol. 2008, 18 (8), 1459-1469.

(13) Kuhn, H. J.; Braslavsky, S. E.; Schmidt, R. Chemical actinometry. Pure Appl. Chem. 2004, 76 (12), 2105-2146.

(14) Bacardit, J.; Hultgren, A.; Garcia-Molina, V.; Esplugas, S. Biodegradability enhancement of wastewater containing 4-chlorophenol by means of Photo-Fenton. J. Adv. Oxid. Technol. 2006, 9 (1), 27-34.

(15) Standard Methods for the examination of water and wastewater, 16th ed.; American Public Health Association: Washington, D.C., 1985.

(16) Stumm, W.; Morgan, J. J. Aquatic chemistry, 2nd ed.; Wiley: New York, 1991.

(17) Henze, M.; Gujer, W.; Mino, T.; van Loosdrecht, M. Activated sludge models ASM1, ASM2, ASM2d and ASM3; Scientific and Technical Report No 9. IWA Publishing: London, 2000.

(18) Sahinkaya, E.; Dilek, F. B. Effect of biogenic substrate concentration on chlorophenol degradation kinetics. J. Chem. Technol. Biotechnol. 2006, 81 (9), 1530-1539.

(19) Wingender, J., Neu, T. R., Flemming, H.-C., Eds. Microbial Extracellular Polymeric Substances: Characterization, Structure and Function; Springer: Berlin, 1999.

(20) Kageyama, C.; Ohta, T.; Hiraoka, K.; Suzuki, M.; Okamoto, T.; Ohishi, K. Chlorinated aliphatic hydrocarbon-induced degradation of trichloroethylene in Wautersia numadzuensis sp. nov. Arch. Microbiol. 2005, 183 (1), 56-65.

(21) Vinas, M.; Sabate, J.; Espuny, M. J.; Solanas, A. M. Bacterial community dynamics and polycyclic aromatic hydrocarbon degradation during bioremediation of heavily creosote-contaminated soil. Appl. Environ. Microbiol. 2005, 71 (11), 7008-7018.

Received for review October 21, 2009 Revised manuscript received January 21, 2010 Accepted January 25, 2010

IE901642U 